\title{
Music Teachers' Usage of the Breathing and Voice Exercises in Song Teaching
}

\author{
Gulnihal Gul \\ Correspondence: Gulnihal Gul, Department of Music Education, Uludag University, Bursa, Turkey.
}

Received: May 22, 2018

doi:10.11114/jets.v6i9.3429
Accepted: June 26, $2018 \quad$ Online Published: July 9, 2018

URL: https://doi.org/10.11114/jets.v6i9.3429

\begin{abstract}
Singing has a profound effect on the child's mental and emotional development and is directly related to the basic mental functions and physiological development. In this context, it is considered that voice training with the aim of using the voice correctly and effectively is necessary in the general music education and breathing and voice exercises have a particular importance for good and quality sound production in this process.

With this idea, in this research, it was aimed to determine the situation of music teachers in Turkey on using breathing and voice exercises while singing in events held in the context of the general music education. According to findings obtained from the research, it has been determined that music teachers' usage of breathing and voice exercises differ according to the institution they are studying, the weekly hours of the music lesson and the inadequacy of the classroom equipment influenced the use of breathing and voice exercises by music teachers in song teaching and teachers felt that they were sufficient enough to accompany themselves to voice exercises.
\end{abstract}

Keywords: song teaching, breathing exercises, voice exercises

\section{Introduction}

Training the voice, which has two important functions in human life such as talking and making music and is thought as the most natural, most useful, the most competent and the most effective tool in making - creating music enables the individuals to use the voice correctly, effectively and beautifully throughout their life (MEB,2018, p.7; Birol, 2003, p.114).

For this purpose, planned and carried out as scheduled voice training; is defined as an interaction process in which the individuals gains necessary behaviors to use their voice in accordance with his / her anatomical and physiological characteristics while speaking and singing in order to create positive changes while protecting the naturalness and health of the throat (Töreyin, 2008, p. 82; Topbaş and Sönmez, 2015, p.2).

As an important educational tool and field, it is necessary that music education should functionally take place within the educational process aimed at attaining positive attitude, knowledge and behavior (Kocabaş, 1997, p.141). Music education, which is included in general education within the scope of institutional education, provides important contributions to the development of subjects such as perception of life, interpretation, creativity, improvement of thinking system and improvement of communication skills (Köksal, 2000, p. 100). In this context, it is thought that voice training has a particular importance in the general music education process as a process of gaining necessary musical behaviors with the aim of using the voice correctly and effectively while talking and singing (Çevik, 1997, p. 68; Say, 2002, p. 476).

Within the scope of voice training, the aim of singing education which takes place in general and volunteer music education and applied in elementary and secondary schools, in particular, is to make individual's voice to acquire the correct, beautiful and effective using behaviors with rhythm, melody, language and hearing exercises (Mustan, 2010, p. 21). Singing with his/her voice which is the first instrument of the people is an important way for the development of his/her voice. For this reason, music teacher should teach the child to use his / her natural voice while teaching the child to sing, using correct posture, correct breathing, and voice, diction and articulation exercises should also be included in the singing lessons for this purpose.

It is seen that singing activities are placed at every grade level when examined primary and secondary school music courses in Turkey. However, in the middle school music curriculum, it has been found out that there is no explanation for breathing and voice exercises in listening-singing achievements (MEB, 2018). 
When international studies are examined, it is stated that it is necessary to include breathing and voice exercises in the singing activities for the reason that they are important contributors to the correct, beautiful and effective use of the child's voice ( Rauduvaite, Lasauskiene, Abramauskiene\& Chuang, 2017; Phillips, Williams\&Edwin, 2011; Kenney, 2011; Phillips \& Vispoel, 1990).

The studies concerning the necessity of giving place to breathing and voice exercises in the song teaching has been identified in studies conducted in Turkey. Mutlu Yıldız and Karakelle (2017) state that, music teachers should perform breathing and voice exercises regularly in their singing studies in order to ensure that the child uses his or her voice in a healthy way.

Yiğit (2006) found that children participating in choral studies learn the basic elements and basic functions of music while learning the formation of the voice, the sound organ, the qualities and capacity of his/her own voice, the ability to preserve his/her own voice and use it correctly, in addition he has also stated that they are conscious of proper and regular breathing and breathing support.

While Davran (1997) states that the essence of singing art is breathing right; Gürkan Öztürk and Akgün (2007) state that the production of a good and quality voice is only possible with correct breathing.

With this research, it is aimed to determine the situations in which music teachers use breathing and voice exercises in singing activities within the scope of general music education in Turkey; depending on the purpose of the research, the answers of the following questions were sought:

1.Is there a meaningful difference in performing the breathing exercises in song teaching in terms of the gender, the experience, the level of the institution and the institution in which the music teacher has been teaching?

2. Is there a meaningful difference in performing voice exercises in song teaching in terms of the gender, the experience, the level of the institution and the institution in which the music teacher has been teaching?

3. Is there a meaningful difference in terms of competence when music teachers accompany voice exercises?

4. What are the opinions of the music teachers on the reasons why they use breathing exercises in song teaching?

5. What are the opinions of the music teachers on the reasons why they use breathing exercises partially in song teaching?

6. What are the opinions of the music teachers on the reasons why they don't use breathing exercises in song teaching?

7.What are the opinions of the music teachers on the reasons why they use voice exercises in song teaching?

8. What are the opinions of the music teachers on the reasons why they use voice exercises partially in song teaching?

9. What are the opinions of the music teachers on the reasons why they don't use voice exercises in song teaching?

\section{Method}

In this section, the information on the research design, the sampling and obtaining of the data is given.

\subsection{The Research Design}

In the study, field survey (survey method) was used to determine the situations in which music teachers use breathing and voice exercises in song teaching. In order to determine the present situation, the survey was directed to the sampling group in the field survey. One of the most frequently used data collection techniques in social sciences, the survey is being used in a short time to obtain superficial data from a large sample (Gönç Şavran, 2012; p. 80). The survey contains demographic characteristics of the participants and structured questions about the use of breathing and voice exercises in song teaching. It is aimed to determine the current situation with the prepared survey; whether this situation varies according to gender, professional experience, the institutions and the level of the institutions which teachers have been teaching, and the reasons why the music teachers include/don't include breathing and voice exercises in singing activities.

Since the survey prepared for the research is prepared to determine the situation and there are no means to use as a measurement or attitude tool; the reliability tests used today cannot be tested. Therefore the attendees' direct answers are cited to increase the reliability of the study. In addition, to ensure the content validity of the survey, the survey questions were asked to three experts in the field, according to expert opinion the survey questions has taken its final form for application.

\subsection{The Population and the Sample of the Research}

The music teachers working in Turkey constitute the population of the study. Volunteerism was adopted during the gathering of the data and music teachers who agreed to participate in the survey responded to the survey. Accordingly, 
228 music teachers working in 47 different cities in Turkey constitute the sample of the research.

The demographic information of the music teachers participating in the research are given in Table 1.

Table 1. Distribution of music teachers attending to research according to gender- experience- level of the institution and institution in which the music teacher has been teaching

\begin{tabular}{lll}
\hline Variables & $\mathrm{n}$ & $\%$ \\
\hline Gender & & 67.11 \\
Memale & 153 & 32.89 \\
\hline Professional Experience & 75 & 36.40 \\
\hline 0-5 Years & 83 & 19.74 \\
6-10 Years & 45 & 17.11 \\
11-15 Years & 39 & 10.53 \\
16-20 Years & 24 & 16.23 \\
\hline More than 20 Years & 37 & 76.75 \\
\hline Starking Institution School & & 23.25 \\
\hline Private School & 175 & 7.89 \\
\hline Level of Institution & 53 & 61.40 \\
\hline Primary School & & 30.70 \\
\hline Secondary School & 18 & $\mathbf{1 0 0}$ \\
\hline
\end{tabular}

\subsection{The Collection and the Analysis of Data}

The survey prepared for the research was prepared online through the internet site "http://www.online-anket.gen.tr" in the computer environment. All teachers were reached online and their opinions were taken. There are 22 questions structured in the prepared survey. 5 of the questions were asked to determine the demographic characteristics. The quantitative data analysis method was used to determine whether music teachers use breathing and voice exercises in teaching songs and how this varied according to various variables and the reasons for using or not using breathing and voice exercises were obtained by qualitative data analysis method.

Music teachers' use of breathing and voice exercises in song teaching were resolved with frequency and percentage calculations. A chi-square test was performed using the SPSS-23 package program to determine whether there was a significant difference between breath and voice exercises in terms of different variables.

The reasons why teachers use or don't use breathing and voice exercises in teaching songs have been tried to be explained through descriptive analysis. Descriptive analysis often includes a direct citation with the purpose of reflecting participants' views (Yıldırım \& Şimşek, 2006, p. 224). 


\section{Results}

In this section, findings obtained with data collection tool are included.

Table 2 shows the results of the chi-square test about the teachers' usage of the breathing exercises in song teaching in terms of various variables.

Table 2. Chi-square test results about the usage of breathing exercise in singing teaching with various variables

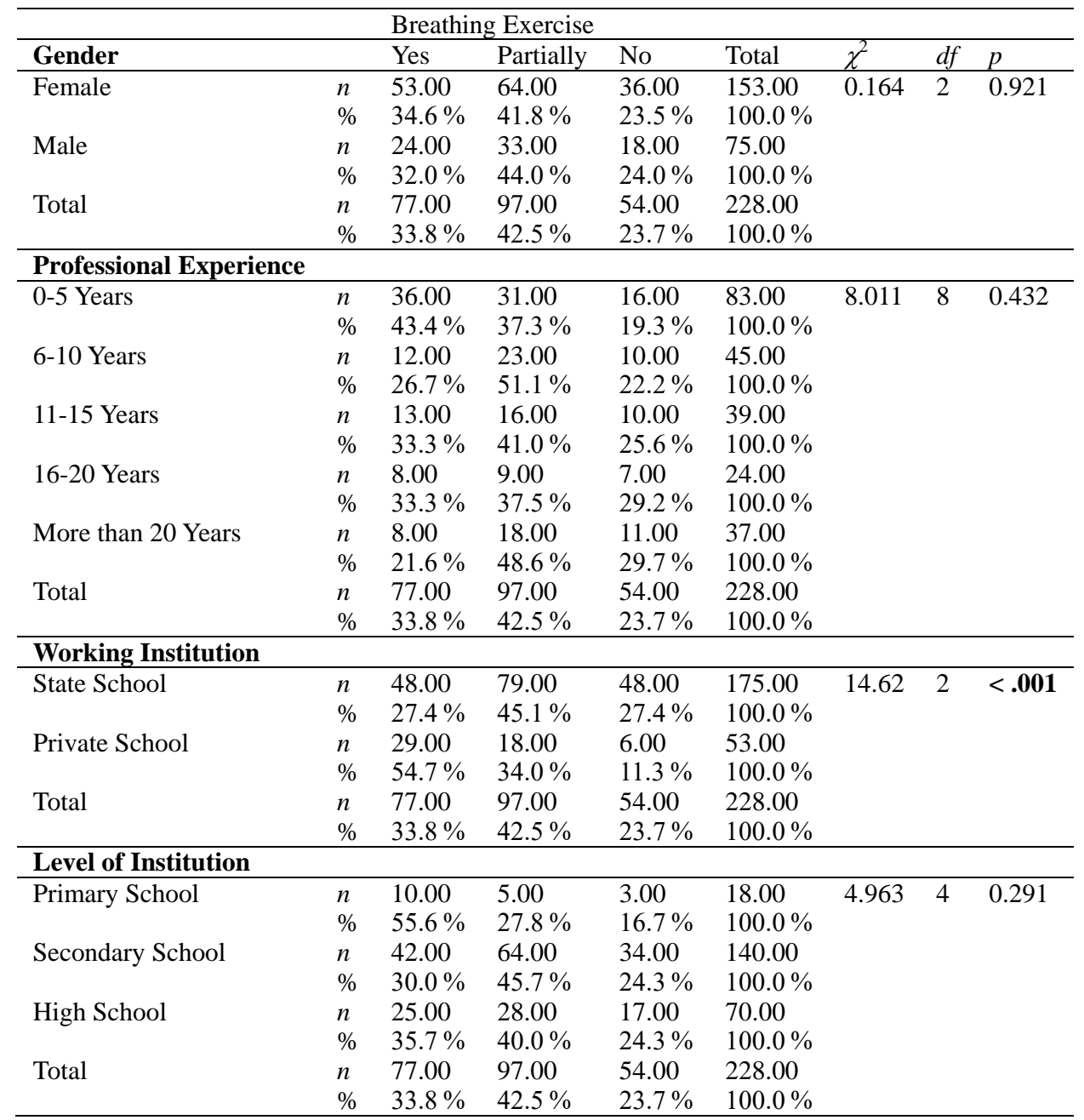

When Table 2 is examined, it is seen that the music teachers' usage of breathing exercises according to sex is $\chi 2(2)=$ $0.164, p=0.921$, according to occupational experience is $\chi 2(2)=8.011, p=0.432$ and they do not differ. However, it is seen that the state of using breathing exercise changes according to the institution which teachers has been working, $\chi 2$ $(2)=14.62, p<.001$. While the proportion of teachers who use the breathing exercises in public schools is $27.4 \%$, this ratio has reached $54.7 \%$ in private schools. The proportion of teachers who did not use the breathing exercises at all in public schools was $27.4 \%$, while this was only $11.3 \%$ in private schools. According to these results, it can be said that the teachers in private schools give more place for breathing exercises.

Table 3 shows the results of the Chi-Square test about the teachers' usage of the voice exercises in song teaching in terms of various variables. 
Table 3. Chi-square test results about the usage of voice exercise in singing teaching with various variables

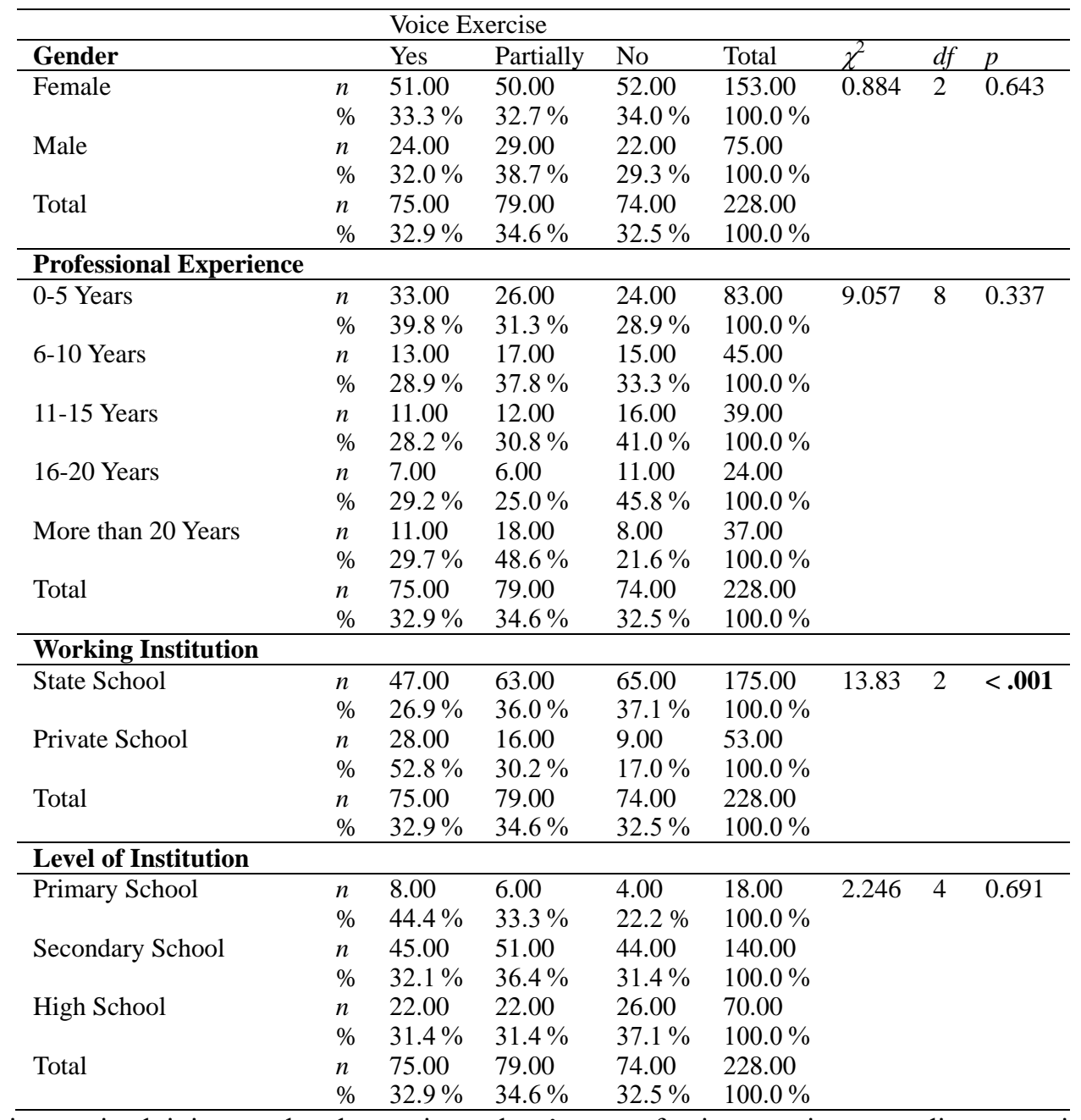

When Table 3 is examined, it is seen that the music teachers' usage of voice exercises according to sex is $\chi^{2}(2)=0.884$, $\mathrm{p}=0.643$, according to occupational experience is $\chi^{2}(2)=9.057, \mathrm{p}=0.337$ and they do not differ. It has been determined that the teachers' voice exercises differ according to the institution they have been teaching, $\chi^{2}(2)=13.83, \mathrm{p}<.001$. While the proportion of teachers who use the voice exercises in public schools is $26.9 \%$, this ratio has reached $52.8 \%$ in private schools. The proportion of teachers who did not use the voice exercises at all in public schools was $37.1 \%$, while this was only $17.0 \%$ in private schools. According to these results, it can be said that the teachers in private schools give more place for voice exercises.

Table 4 shows the results of the Chi-square test for the competence of music teachers in accompaniment to voice exercises.

Table 4. The results of the chi-square test for the competence of music teachers in accompaniment to voice exercises

\begin{tabular}{lllllllll}
\hline & & Yes & Partially & No & Total & $\chi^{2}$ & $d f$ & $p$ \\
\hline Accompaniment to voice exercises & $\mathrm{n}$ & 138.00 & 72.00 & 18.00 & 228 & 95.053 & 2 & $<.001$ \\
& $\%$ & $60.5 \%$ & $31.6 \%$ & $7.9 \%$ & $100.0 \%$ & & & \\
\hline
\end{tabular}

Table 4 shows that the results of the chi-square test for the competence of music teachers in accompaniment to voice exercises are different, $\chi^{2}(2)=95.83, \mathrm{p}<.001$. According to this, it can be said that the teachers feel that they are competent enough to accompany to the voice exercises.

Table 5 shows the opinions of music teachers about the reasons for using the breathing exercises in song teaching. 
Table 5. Reasons for music teachers using breathing exercises in song teaching

\begin{tabular}{lc}
\hline & $\mathrm{n}$ \\
\hline Positively affect the voice control & 24 \\
For breath control & 22 \\
It contributes to accurate and effective singing & 13 \\
For the health of the voice & 8 \\
Increasing the concentration of the student & 4 \\
It affects entonation positively & 3 \\
\hline
\end{tabular}

When Table 5 is examined, it is observed that the primal reason why music teachers use breathing exercises in teaching songs is that these exercises have a positive effect on the voice control of the students $(n=24)$. In addition, breath control is one of the reasons why teachers use breathing exercises $(n=22)$. Teachers have expressed the following views on the reasons for using breathing exercises before teaching songs:

"I believe it's important to control breathing to produce good voice (P42)", "Like training before going to the football field (P73)", "There is a positive effect in expressing the sentences in the song much more clearly (P94)", "It helps me to motivate children for the lesson (P120)".

Table 6 shows the opinions of music teachers on the reasons why they use breathing exercises partially in song teaching.

Table 6. Reasons for music teachers using breathing exercises partially in song teaching

\begin{tabular}{ll}
\hline & $\mathrm{n}$ \\
\hline With the reason of insufficient time & 55 \\
Students do not take breathing exercises seriously & 5 \\
Feeling insufficient in breathing exercise & 4 \\
Varying according to the course content & 2 \\
Hardware inadequacy & 2 \\
\hline
\end{tabular}

When Table 6 is examined, the primal reason why music teachers use breathing exercises partially in song teaching is insufficient time $(n=55)$. In addition,Feeling insufficient in breathing exercise, hardware inadequacy, the tendency of the students not taking these exercises seriously, and varying according to the course content are among other reasons. Teachers have expressed the following views on the reasons for performing breathing exercises partially before teaching songs:

"In this regard, I am not very adequate (P2)", "When students make these exercises, they get disconnected (P32)", "They are happy while singing. However, the course is only 40 minutes a week and during this time I have to perform note teaching, solfege, subject expression and instrument teaching. For this reason, I do not have enough time for breathing exercises (P173) ", "My knowledge of this subject is rather limited (P218)".

Table 7 shows the opinions of music teachers about why they do not use breathing exercises in song teaching.

Table 7. Reasons for music teachers not using the breathing exercises in song teaching

\begin{tabular}{ll}
\hline & $\mathrm{n}$ \\
\hline With the reason of insufficient time & 32 \\
Hardware inadequacy & 3 \\
Crowded classes & 3 \\
Not teaching songs & 1 \\
Not feeling the need & 1 \\
Forgetting to use breathing exercise & 1 \\
\hline
\end{tabular}

When Table 7 is examined, the primal reason why music teachers not using breathing exercises in song teaching is insufficient time $(n=32)$. Not feeling the need, forgetting to use breathing exercise, and not teaching songs are among other reasons. Teachers have expressed the following views on why they do not have breathing exercises before teaching songs:

"Students do not sing in lessons (P70)", "Music lesson is 1 lesson per week, 40 minutes. I think it is utopian to both treat a subject and to use breathing and voice exercises during this time (P212)".

Table 8 shows the opinions of music teachers about the reasons for using the voice exercises in song teaching.

Table 8. Reasons for music teachers using voice exercises in song teaching

\begin{tabular}{ll}
\hline & $\mathrm{n}$ \\
\hline To produce the right voice & 14 \\
It makes a positive impact on clean singing & 8 \\
It affects communication with the student positively & 3 \\
To provide voice control & 2 \\
\hline
\end{tabular}

When Table 8 is examined, it is seen that music teachers include voice exercises in song teaching because of the 
production of correct voice, providing voice control, clean singing and positive effects on communication with the student. Teachers have expressed the following opinions about the reasons for using voice exercises before teaching songs:

"Students are doing voice exercises with great pleasure. These exercises are increasing their interest in the class (P175)", "It attracts interests and also provides a positive contribution to my communication with my students (P180)".

Table 9 shows the opinions of the music teachers on the reasons for why they use voice exercises partially in song teaching.

Table 9. Reasons for music teachers to use voice exercises partially in song teaching

\begin{tabular}{ll}
\hline & $\mathrm{n}$ \\
\hline With the reason of insufficient time & 45 \\
Hardware inadequacy & 4 \\
Students get bored during the exercises & 3 \\
Feeling insufficient in voicing exercise & 2 \\
Not feeling the need for every song & 2 \\
Varying according to the course content & 1 \\
Not teaching songs & 1 \\
\hline
\end{tabular}

When Table 9 is examined, the primal reason why music teachers use voice exercises partially in song teaching is insufficient time $(f=45)$. In addition to this, hardware inadequacy, feeling insufficient in voicing exercise and boredom of students during these exercises are among other reasons. Teachers have expressed the following opinions about the reasons for using voice exercises partially before teaching songs:

"Not necessary for every song (P23)", "I can not make it in some classes. Because it's very difficult to focus their attention. Also because of the lesson time, I sometimes go to singing without exercising (P167) ".

Table 10 shows the opinions of music teachers about why they do not use voice exercises in song teaching.

Table 10. Reasons for music teachers not using the voice exercises in song teaching

\begin{tabular}{ll}
\hline & $\mathrm{n}$ \\
\hline With the reason of insufficient time & 30 \\
Hardware inadequacy & 13 \\
Distraction of the students during the exercise & 5 \\
Feeling insufficient in voice exercises & 2 \\
Not feeling the need of exercise & 1 \\
Crowded classes & 1 \\
Students are not singing during the class & 1 \\
Forgetting to use the exercise & 1 \\
\hline
\end{tabular}

When Table 10 is examined, the primal reason why music teachers don't use voice exercises in song teaching is insufficient time just like the primal reason why music teachers use voice exercises partially $(\mathrm{n}=30)$. In addition to this, it is observed that the hardware inadequacy is the second reason for not using voice exercises $(n=13)$. It has been found out that students are distracted during exercises, the teachers feel inadequate, and crowded classes are among the reasons why teachers do not include voice exercises. Teachers have expressed the following opinions about the reasons for not using voice exercises before the song teaching:

"I do not do it because of time concerns. I am a teacher in high school and this group of children is distracted very quickly. For this reason, I immediately go to song teaching (P15)", "We do not have a music class. I cannot teach comfortably because other classes are disturbed (P29)", "I do not want to bore children with technical studies (P65)", "I only find breathing exercises satisfactory (P92)".

\section{Discussion}

Within the scope of general music education, it is aimed at students to gain proper behaviors towards the correct use of the voice and protection habits by singing beautiful and effective with voice education (Töreyin, 2008, p. 106). For this purpose, in the context of voice education, it is considered that breathing and voice exercises are important as a basis for realizing the targeted behaviors.

As a result of this research, when the music teachers' usage of breathing and voice exercises in song teaching is examined, it is seen that music teachers who work in private schools give breathing and voice exercises a place more than the music teachers who work in public school. According to the results of the research, it is thought that this situation is caused by the lack of equipment and 1 hour of music lessons per week in public schools. Correct and effective use of the human voice which is the most natural instrument is subject to a systematic training and education environment.(Sarac, 2001). Ensuring that the students can use their voice correctly and effectively during the general music education process will positively influence their usage of music education and voice in the future. For this reason, 
it is very important for teachers to include their breathing and voice exercises in song teaching. However, the lack of lesson time especially in public schools negatively affects the effective implementation of this education. With this thought, it is necessary to increase the weekly hours of the music course and to make the training environments suitable for music education.

Researches show that the speaking and singing habits of the children and adolescents which are influenced by the increase in the level of life and popular cultures, significantly increased voice illnesses and voice health is severely damaged (Töreyin, 2008, p. 105). For this reason, it is expected that behaviors related to the habits such as correct usage of the voice and protection of the voice are expected to be provided in the institutions providing general music education; it is thought that breathing and voice exercises should not be neglected during the singing process in this direction.

As a result of the research, it has been found that music teachers are aware of the necessity to include breathing and voice exercises in song teaching. However, some of the teachers seem to think that they feel completely or partially inadequate to do these exercises. For this reason, in the institutions that train music teachers, lectures about methods and techniques of sound pedagogy teaching methods should be included in the undergraduate programs. Teachers 'manuals, prepared by the Ministry of National Education should include examples of breathing and voice exercises appropriate to the song and age group characteristics to be taught before teaching the song, thereby contributing to the elimination of teachers' inadequacies until the necessary arrangements have been made.

\section{References}

Birol, G. (2003). The İmportance of İndividual Voice Education in Terms of Proper, Correct and Effective Speech to Music Teacher Candidates, Cumhuriyetin 80. Yllında Müzik Sempozyumu (s.111-115). Malatya: Öncü Matbaası.

Çevik, S. (1997). Choral Education and Management Techniques, Ankara: Doruk Yayınc1lık.

Davran, Y. (1997). A History of The Art Of Singing, Ankara: Evrensel Müzikevi.

Gönç, Ş.T. (2012). Research Techniques Used in Quantitative and Qualitative Research, T. Gönç Şavran . (Eds.), Sosyolojide Araştırma Yöntem ve Teknikleri, (ss. 64-104). Anadolu Üniversitesi Web Ofset, Eskişehir.

Kenney, S. (2011). Teaching Young Children How To Sing: One School's Experience, General Music Today, 24(2), 52-56. https://doi.org/10.1177/1048371310385803

Kocabaş, A. (1997). Validity and Reliability of The Attitude Scale for Music Basic Education II. Grade Students, Hacettepe Üniversitesi Ĕgitim Fakültesi Dergisi, 13, 141-145.

Köksal, A. (2000). Examination of Empathic Skills and Adaptation Levels of Adolescents According to Gender and Class Level Variables, Hacettepe Üniversitesi Eğitim Fakültesi Dergisi, 18, 99-107.

MEB. (2018). Music Lesson Curriculum, (İlkokul ve Ortaokul 1, 2, 3, 4, 5, 6, 7 ve 8. Sinıflar). Ankara: Milli Eğitim Bakanlığı Yayınları.

Mustan, H. (2010). A Survey on Difficulties Faced by 12. Class Students in Vocal Education Lessons at The Music Departments of Anatolian Fine Art and Sports High Schools, Konya: Selçuk Üniversitesi Eğitim Bilimleri Enstitüsü, Unpublished Master's Thesis.

Mutlu, Y. Y., \& Karakelle, S. (2017). Musical Development Characterıstıcs of Primary Education Students and Music Education, Uluslararası Sosyal Araştırmalar Dergisi, 48(10), 494-500.

Öztürk, G. F., \& Akgün, G. (2007). Voıce Education and 3 R Rule, Kastamonu Eğitim Dergisi, 15(1), 423-426. http://www.kefdergi.com/pdf/15_1/423.pdf

Phillips, K. H., \& Vispoel, W. P. (1990). The effects of class voice and breath-management instruction on vocal knowledge, attitudes, and vocal performance among elementary education majors. The Quarterly Journal of Music Teaching and Learning, 1, 96-105.

Phillips, K., Edwin, R., \& Williams, J. (2011). Supplemental Singing Exercises, Supplement to the Oxford Handbook of Music Education. http://www.robertedwinstudio.com/supplemental-singing-exercises.php.

Rauduvaite, A., Lasauskiene, J., Abramauskiene, J., \& Chuang, M. J. (2017). Children's Singing: Reflections on a Vocal Teaching in Lithuania and Taiwan, International Journal of Social Sciences, 3(1), 853-869. https://doi.org/10.20319/pijss.2017.s31.853869

Saraç, H. (2001). Bireysel Ses Eğitiminde Fonasyon'un Önemi ve Özellikleri, Güzel Sanatlar Enstitüsü Dergisi, 7 , 93-96. http://dergipark.gov.tr/download/article-file/28598

Say, A. (2002). Music Dictionary. Ankara: Müzik Ansiklopedisi Yayınları. 
Toptaş, B., \& Sönmez, A. (2015). Effects on the Right and Effective Speaking Skills of Individual Voice Training Course in School of Fine Arts Department of Music, Inönü Üniversitesi Kültür ve Sanat Dergisi, 1(1), 1-15. http://dergipark.ulakbim.gov.tr/ijca/article/view/5000101961

Töreyin, A. M. (2008). Voice Education (Basic Concepts -Principles - Methods). Ankara: Sözkesen Matbaacılık.

Yıldırım, A., \& Şimşek, H. (2006). Qualitative Research Methods in Social Sciences. Ankara: Seçkin Yayınları.

Yiğit, N. (2006). Effects Of Choral Sound Education Studies On Children's Sound Development, Selçuk Üniversitesi Sosyal Bilimler Enstitüsü Dergisi, 16, 777-783. dergisosyalbil.selcuk.edu.tr/susbed/article/download/559/539

\section{Copyrights}

Copyright for this article is retained by the author(s), with first publication rights granted to the journal.

This is an open-access article distributed under the terms and conditions of the Creative Commons Attribution license which permits unrestricted use, distribution, and reproduction in any medium, provided the original work is properly cited. 